\begin{tabular}{|l|c|} 
Proceeding of the $^{\text {th }}$ ICEE Conference 3-5 April 2018 & CEA \\
Military Technical College \\
Kobry El-Kobbah, \\
Cairo, Egypt
\end{tabular}

\title{
CEA-1
}

\section{A Green Method for the Determination of Mebeverine in Its Pharmaceutical Products and Human Serum Based On Diatom Modified Carbon Paste Electrode Using Square Wave Adsorptive Anodic Stripping Voltammetry (SW-AdASV)}

\author{
$\underline{\text { Fared M. El-badawy }^{\mathrm{a}, \mathrm{b}}}$, Hanaa S. El-Desoky ${ }^{\mathrm{a}}$ and Mohamed M. Ghoneim ${ }^{\mathrm{a}}$
}

\begin{abstract}
The first use of a green method of analysis using diatom for trace determination of mebeverine in its pharmaceutical formulation and human serum based on its great properties such as high surface area, hydrophilicity, and adsorption. in addition to diatom requires no chemical modification. Characterization of Diatom using FTIR showed bands corresponding to $\mathrm{AlMgOH}, \mathrm{Si}-\mathrm{O}-\mathrm{Al}, \mathrm{SiOH}$, and $\mathrm{OH}$, while XRD showed that diatom is amorphous containing silica of quartz crystal shape, SEM revealed that diatom has porous surface. Cyclic Voltammetry of the modified electrode revealed that the modified electrode has higher surface area and greater adsorption. Mebeverine hydrochloride (MV.HCl) was determined based on 5\% diatom modified carbon paste electrode 5\% $(\mathrm{w} / \mathrm{w}) \mathrm{DA} / \mathrm{CPE}$ as a sensor with LOD and LOQ of $1.80 \times 10^{-9}$ and $6.00 \times 10^{-9}$ respectively. Then, the modified electrode was successfully applied for the trace determination of $\mathrm{MV} . \mathrm{HCl}$ in different pharmaceutical preparations; "Coloverin A", "Colona" and "Colofac" tablets without interferences from excipients and co-formulated drugs. The achieved detection limit in human serum was $8.0 \times 10^{-9} \mathrm{M}$. The described adsorptive anodic stripping voltammetric method is reliable, simple, and sensitive enough for assay of $\mathrm{MV} . \mathrm{HCl}$ in real plasma samples, pharmacokinetic studies, quality control and assurance of the drug in industry and in clinical laboratories.
\end{abstract}

\section{Keywords:-}

Square wave anodic stripping voltammetry; SW-AdASV; diatom; Mebeverine

\footnotetext{
a Analytical and Electrochemistry Research Unit, Department of Chemistry, Faculty of Science, Tanta University, 31527 Tanta, Egypt

${ }^{b}$ Egyptian Ministry of Industry, Chemistry Administration, Cairo, Egypt
} 


\section{Military Technical College \\ Kobry El-Kobbah, Cairo, Egypt}

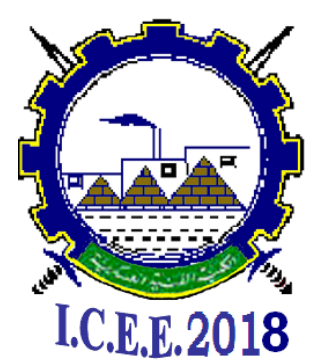

$9^{\text {th }}$ International Conference on

Chemical \& Environmental Engineering

3-5 April 2018

\section{Introduction}

Mebeverine hydrochloride (MV.HCl) has the IUPAC name 3,4-dimethoxybenzoic acid 4-[ethyl-(2-[4-methoxyphenyl] -1-methylethyl) -amino] butyl ester (Fig. 1) potent direct antispasmodic agent used mainly for the smooth muscles of the gastrointestinal tract and particularly effective against the colonic spasm [1] It is used in the treatment of abdominal pain and spasm associated with gastrointestinal disorders such as mucous colitis [2]

Due to the vital importance of $\mathrm{MV} . \mathrm{HCl}$, there are many reported methods for its determination in its pharmaceutical formulations and in biological fluids. Among these methods are HPLC[3-7], spectrophotometry [8-11], GC-MS [12], and electrochemistry [13-16].

On one side, most of the reported chromatographic is expensive method of analysis required a high maintenance cost, high acquisition cost, time-consuming procedures, senetive equilibration, it also may requires derivatization treatment prior to analysis and expensive grades of reagents, eluents, and equipment [3-7, 12],

On other side, there are some reported electrochemical methods based on potentiometry [13], square-wave anodic stripping voltammetry (SW-ASV) [14, 16] and differential pulse voltammetry (DPV) [15] listed in (Table 1). It is noticed that Potentiometry and SW-AdASV onto bare Carbon paste electrode CPE did not offer a sufficient sensitive quantitation limit of $\mathrm{MV} . \mathrm{HCl}$ that can cover pharmacokinetic studies and therapeutic drug monitoring. Duo to the $\mathrm{MV} . \mathrm{HCl}$ conc in plasma was reported to be less than $10 \mathrm{ng}$. $\mathrm{mL}^{-1}\left(<2.15 \times 10^{-8} \mathrm{M}\right)$ after a single oral dose of $405 \mathrm{mg}$ of mebeverine hydrochloride [6] or in the range of 25 to $0.73 \mathrm{ng} \mathrm{mL} \mathrm{m}^{-1}\left(5.36 \times 10^{-8} \mathrm{M}\right.$ to $\left.1.57 \times 10^{-9} \mathrm{M}\right)$ after oral administration of two Colona ${ }^{\circledR}$ tablets (100 mg Mebeverine $+25 \mathrm{mg}$ Sulpiride)[7]. The other SW-AdASV using gold nanoparticles/silica gel [15] indicated narrow linear segment variations of the $\left(i_{p}\right)$ with $\mathrm{MV} . \mathrm{HCl}$ conc. in addition to hard procedures of preparation and expensive chemicals, moreover, the reported SW-AdASV on functionalized multiwall carbon nanotube modified carbon paste electrode dependes on in expensive materials, which was further functionalized.

Since the modification of the carbon paste electrode depend on modifying the properties which help in those modifications. First, the chemical composition of diatom contains hydrous silica compositions $\left(\mathrm{SiO}_{2} \cdot \mathrm{nH}_{2} \mathrm{O}\right)$, in which water is bounded within a siliceous skeleton. It may also contains small amounts of associated inorganic components like alumina, principally or lesser amounts of iron, alkaline earth or alkali metals, and/or other minor constituents [17] So, it is mainly hydrophilic with many functional groups responsible for adsorption such as $[\equiv \mathrm{SiOH}],[=\mathrm{Si}(\mathrm{OH}) 2],[\equiv \mathrm{Si}-\mathrm{O}-\mathrm{Si} \equiv]$ and other hydrogen bond forming groups $[18,19]$. In addition to the morphological structure of the diatom and its 
Military Technical College

Kobry El-Kobbah, Cairo, Egypt

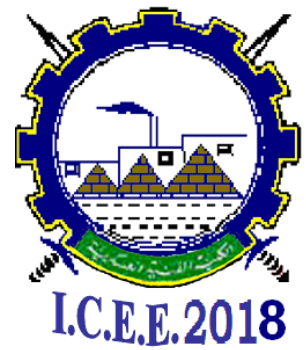

$9^{\text {th }}$ International Conference on

Chemical \& Environmental Engineering

3-5 April 2018

porous surface that contribute in increasing the surface area and hence increasing the accumulating amount of the analyte in the preconcentration step,

\section{Experimental}

\subsection{Apparatus}

Voltammetric measurements were performed with Princeton Applied Research (PAR, Princeton, Oak Ridge, TN, U.S.A.) Potentiostats Models 273 A and 263 A. A voltammetric cell consisting of a C-2 stand with a carbon paste working electrode (BAS Model MF-2010, $3 \mathrm{~mm}$ in diameter and $1 \mathrm{~mm}$ in depth), an $\mathrm{Ag} / \mathrm{AgCl} / \mathrm{KCl}_{\mathrm{s}}$ reference electrode (BAS Model MF-2063) and a platinum wire counter electrode (BAS Model MW-1032) were used.

Fourier transform infrared (FTIR) spectra were measured with Thermo scientific nicolet iS50 FTIR, USA.

JSM-6510 LV, JEOL-Japan (with Gold coating unit: SPI-Module sputter coater) scanning electron microscope (SEM) was used to observe the surface morphology of the carbon paste $(\mathrm{CP})$ and the modified $\mathrm{CP}$ with various ratios of diatom.

\subsection{Materials}

Diatom was locally prepared, and Mebeverine hydrochloride (MV.HCl) stander and (Colona tablets $^{\circledR}$ each tablet contains $100 \mathrm{mg}$ mebeverine $+25 \mathrm{mg}$ sulpiride) was kindly provided by Bayer Pharmaceuticals (Middle East) Rameda Company, Egypt.

Other pharmaceutical samples examined in this work: Colofac ${ }^{\circledR}$ tablets (BGP Products, Egypt, each tablet contains $135 \mathrm{mg}$ mebeverine), and Coloverin $\mathrm{A}^{\circledR}$ tablets (Chemi Pharm Company, Egypt, each tablet contains $135 \mathrm{mg}$ mebeverine $+5 \mathrm{mg}$ chloridazepoxide).

\subsection{Preparation of mebeverine hydrochloride and drug product solutions}

A standard stock solution of $1.0 \times 10^{-3} \mathrm{M}$ MV.HCl was prepared in methanol (Merck) and stored in the dark at $4^{0} \mathrm{C}$. A more dilute solutions of $\left(1.0 \times 10^{-8}\right.$ to $\left.1.0 \times 10^{-4} \mathrm{M}\right) \mathrm{MV} . \mathrm{HCl}$ were prepared daily in methanol just before use.

Ten tablets of each of the pharmaceutical products of $\mathrm{MV} . \mathrm{HCl}$ were weighed and the average mass per tablet was determined, and then grounded to a fine powder. A weighed portion of the homogeneous powder equivalent to $1.0 \times 10^{-3} \mathrm{M} \mathrm{MV} . \mathrm{HCl}$ was accurately transferred into a $100-\mathrm{mL}$ volume calibrated flask containing $70 \mathrm{~mL}$ methanol. The content of the flask was sonicated for about $10 \mathrm{~min}$ and then filled up with methanol. Convenient more-dilute working solutions were then obtained by accurate dilution with methanol. 
Military Technical College

Kobry El-Kobbah, Cairo, Egypt

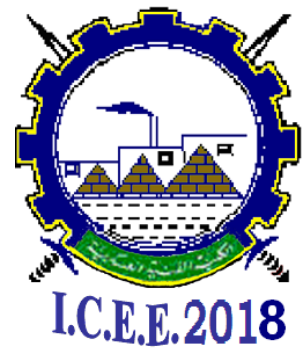

$9^{\text {th }}$ International Conference on

Chemical \& Environmental

Engineering

3-5 April 2018

\subsection{Serum sample preparation}

Six serum samples of three healthy volunteers were stored frozen until assay. $1 \mathrm{~mL}$ of each sample were fortified with various concentrations $\left(1.0 \times 10^{-8}\right.$ to $\left.1.0 \times 10^{-3} \mathrm{M}\right)$ of $\mathrm{MV} . \mathrm{HCl}$ in small centrifugation tubes then completed to $2 \mathrm{~mL}$ with methanol to denature and precipitate proteins. After vortexing each of the serum samples for $2 \mathrm{~min}$, the precipitated proteins were separated by centrifugation for 3 min at 14,000 rpm. The clear supernatant layers were filtered through $0.45 \mu \mathrm{m}$ Milli-pore filters to obtain protein-free spiked human serum samples.

\subsection{Preparation of the Carbon Paste Electrodes (CPEs)}

The working electrode was a Teflon rod with end cavity ( $3 \mathrm{~mm}$ diameter and $5 \mathrm{~mm}$ deep) bored at one end for paste filling (BASi-MF-2010) and contact was made with a copper wire through the centre of the rod. The carbon paste was prepared by thoroughly hand mixing $5 \mathrm{~g}$ of graphite powder (Sigma-Aldrich, Milwaukee, WI, US 1-2 $\mu \mathrm{m}$ ) with $1.8 \mathrm{~mL}$ of paraffin oil (Sigma-Aldrich, US, $\mathrm{d}=0.84 \mathrm{~g} \mathrm{~mL}^{-1}$ ) in an agate mortar with pestle. The paraffin oil-based paste was packed into the well of the electrode and its surface was manually smoothed by polishing on clean paper. Several sweeps of cyclic voltammetry within range of $(-0.4$ to $1.4 \mathrm{~V})$ were applied to the electrode immersed in the supporting electrolyte to obtain a low background current. For electrode surface re-generation, after recording each voltammogram, the CPE was transferred into a blank electrolyte solution and series of cyclic scans were performed until a voltammogram corresponding to the residual current was obtained.

\subsection{Preparation of the modified carbon paste electrode}

An amount (4.5 g) of graphite powder and $0.5 \mathrm{~g}$ of diatom were mixed uniformly by milling in a small agate mortar. Then $1.8 \mathrm{~mL}$ paraffin oil was added and milled again to give a homogenous $10 \%(\mathrm{w} / \mathrm{w}) \mathrm{DA} / \mathrm{CP}$. Various modified carbon pastes containing different mass percentages of diatom $(3,5,7,10$, and $15 \% \mathrm{w} / \mathrm{w})$ were similarly prepared.

\section{Results and discussion}

\subsection{Diatom and DA/CPE characterization}

The FTIR spectrum of Diatom shows a broad band in the range 2900 to $3800 \mathrm{~cm}-1$ (Fig. 2A) with its specific peak at $3447 \mathrm{~cm}^{-1}$, which is attributed to the stretching vibration of the $\mathrm{OH}$ group [20]. As water-bearing mineral, the most distinct feature evident within the Diatom spectra is the bending vibration of the $\mathrm{OH}$ group at $1636 \mathrm{~cm}^{-1}$ [21]. The most intense band at $1105 \mathrm{~cm}^{-1}$ is related to the $\mathrm{Si}-\mathrm{O}$ stretching vibrations. The band at 795 


\section{Military Technical College \\ Kobry El-Kobbah, Cairo, Egypt}

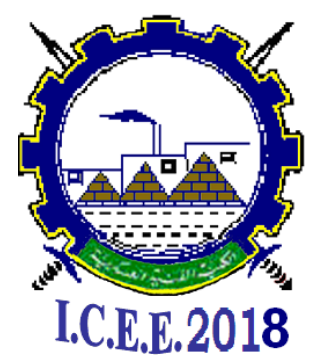

$9^{\text {th }}$ International Conference on

Chemical \& Environmental Engineering

3-5 April 2018

$\mathrm{cm}^{-1}$ is attributed to $\mathrm{AlMgOH}$ bending vibration [20]. The Si-O-Al and Si-O-Si deformation vibrations in Diatom spectrum were observed at $467 \mathrm{~cm}^{-1}$ [20]. The FTIR spectrum revealed that no any function groups are associated with graphite structure, (curve II). It also revealed many characteristic functional Diatom (curve I) compared to graphite (curve II).

$\mathrm{X}$ ray diffraction was recorded for diatom (Fig. 2B) The broad band in the range 15 to 35 confirm the amorphous structure of the diatom[22] while the sharp band at 26.75[23] is characteristic for quartz so some of the silica in the diatom has quartz morphology structure

Continued to show the improved electrochemical properties of the modified electrodes, the microscopic areas of the bare and diatom modified carbon past electrode were calculated using $1.0 \times 10^{-3} \mathrm{M} \mathrm{K}_{4} \mathrm{Fe}(\mathrm{CN})_{6}$ as an electrochemical probe[24] by recording cyclic voltammograms at different scan rates (Fig. 2C). The magnitude of the redox peak currents at the same scanning rate was found to increase obviously after modification, which can be attributed to higher surface area and excellent solution-electrode interact as a result of the decreased hydrophobicity. The following Randles-Sevcik equation (1) For a reversible process can be used[24];

$$
\mathrm{i}_{\mathrm{p}}=\left(2.69 \times 10^{5}\right) \mathrm{n}^{2 / 3} \mathrm{~A} \mathrm{D}^{01 / 2} v^{1 / 2} \mathrm{C}^{\mathrm{o}}
$$

Where, $i_{p}$ refers to the peak current in ampere, $A$ is the surface area of the electrode in $\mathrm{cm}^{2}, \mathrm{n}$ is the electron transfer number, $\mathrm{D}^{\mathrm{o}}$ is diffusion coefficient, $\mathrm{C}^{\mathrm{O}}$ is the concentration of $\mathrm{K}_{4} \mathrm{Fe}(\mathrm{CN})_{6}$ in $\mathrm{M}$ and $v$ is the scan rate in $\mathrm{V} . \mathrm{s}^{-1}$. Linear dependence of the anodic peak currents $\left(\mathrm{i}_{\mathrm{pa}}\right)$ to the square root of scan rate $\left(v^{1 / 2}\right)$ was achieved for bare CPE and $5 \%(\mathrm{w} / \mathrm{w}) \mathrm{DA} / \mathrm{CP} / \mathrm{CPE}$ with correlation coefficient $\left(\mathrm{r}^{2}=0.999\right)$ (Fig. $2 \mathrm{C}$ inside)

For $1.0 \times 10^{-3} \mathrm{M} \mathrm{K}_{4} \mathrm{Fe}(\mathrm{CN})_{6}, \mathrm{n}=1, \mathrm{D}^{\mathrm{o}}=7.63 \times 10^{-6} \mathrm{~cm}^{2} \mathrm{~s}^{-1}[25]$, and from the slope values for the $\mathrm{i}_{\mathrm{pa}}-v^{1 / 2}$ relation are (33.22 and 40.89) for bare CPE and DA/CPE respectively, the microscopic surface areas for bare CPE and DA/CPE were found to be 0.045 , and 0.055 $\mathrm{cm}^{2}$, respectively. So, it was remarkable that the active surface area of DA/CPE was greater than that for bare CPE by about $22.2 \%$.

Scanning electron microscope was used to investigate the used modifier (Fig. 2D) and Shows an amorphous porous pattern of a high surface area also the surface of diatom is porous increasing surface area too. Furthermore, the investigation of both CPE and DA/CPE using SEM showed a rough surface of the modified electrode that leads to a higher surface area of DA/CPE than CPE (Fig. 3), this is due to the rough surface of modified electrode.

Due to the high surface area and hydrophplicity of DA/CPE compared to the bare CPE, $\mathrm{MV} . \mathrm{HCl}$ was determined using this relevant sensor in the present analytical study. 
Military Technical College

Kobry El-Kobbah, Cairo, Egypt

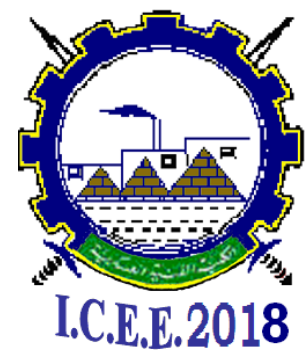

$9^{\text {th }}$ International Conference on

Chemical \& Environmental

Engineering

3-5 April 2018

\subsection{Analytical study}

\subsubsection{Optimization of the modifier ratio}

Square wave voltammograms was recorded $5 \times 10^{-7} \mathrm{MV} . \mathrm{HCl}$ in B-R universal buffer of $\mathrm{pH} 5$ and accumulation parameters $\left(\mathrm{E}_{\mathrm{acc}}=0.0 \mathrm{~V}\right.$ and $\left.\mathrm{t}_{\mathrm{acc}}=50 \mathrm{~s}\right)$ onto the modified carbon paste electrode with different ratios of diatom (Fig. 4). It was found that the well-defined peak with the highest peak current is observed at $5 \%(\mathrm{w} / \mathrm{w}) \mathrm{DA} / \mathrm{CPE}$ so it was used for the rest analytical study.

\subsubsection{Effect of $\mathbf{p H}$ of the medium}

Based on the strong adsorption behavior of $\mathrm{MV} . \mathrm{HCl}$ onto DA/CPE, voltammograms of $5.0 \times 10^{-7} \mathrm{M}$ MV.HCl were recorded in B-R universal buffer of various $\mathrm{pH}$ values following its preconcentration onto the DA/CPE at $0.0 \mathrm{~V}$ for $50 \mathrm{~s}$ (Fig. 5) it was observed that the peak current was increased with $\mathrm{pH}$ increasing till $\mathrm{pH} 5$ then decreased dramatically, then the best developed peak current was at $\mathrm{pH} 5$ so it was used for the rest optimizations.

\subsubsection{Effect of pulse parameters}

It is clearly known that The pulse parameters such as frequency $(f)$, pulse height $(a)$ and scan increment $\left(\Delta E_{s}\right)$ have a great effect on the response obtained by SW-AdASV, the peak current magnitude was investigated by the variation of $f(10-140 \mathrm{~Hz}), \Delta E \mathrm{~s}(2-$ $12 \mathrm{mV}$ ) and $a(5-35 \mathrm{mV})$ on the SW-AdASV onto DA/CPE at $\mathrm{pH} 5$ for determination of $5.0 \times 10^{-7} \mathrm{M} \mathrm{MV} . \mathrm{HCl}$ prior to preconcentration for $50 \mathrm{~s}$ at accumulation potential $0.0 \mathrm{~V}$; The best developed and symmetrical voltammetric peaks were obtained at $f=100 \mathrm{~Hz}$ and $\Delta E_{s}=10 \mathrm{mV}$. However, the pulse height had no influence on $\mathrm{i}_{\mathrm{p}}$. So, $25 \mathrm{mV}$ was used in rest of study.

\subsubsection{Effect of accumulation parameters}

The electrode potential may affect the electric field at the electrode-solution interface, and hence the interfacial tension which is certain to have influence upon the adsorption occurring at this interface [26]. So, the effect of $E_{\text {acc }}$ on the peak current magnitude was tested over the potential range of -0.2 to $+0.6 \mathrm{~V}$. The best enhanced peak current magnitude was achieved at the potential range of 0.0 to $+0.2 \mathrm{~V}$ (Fig. 6). This could be attributed to the increase of the accumulation rate and the favorable alignment of the analyte molecules by the action of electric field at the electrode-solution interface (which may be due to electrostatic attraction between the negative nature of electrode at this potential range and the positive charged (protonated) $\mathrm{MV} . \mathrm{HCl}$ molecules)[27]; but the better peak was observed at $0.0 \mathrm{~V}$ so it was used as the optimum accumulation potential. 


\section{Military Technical College \\ Kobry El-Kobbah, \\ Cairo, Egypt}

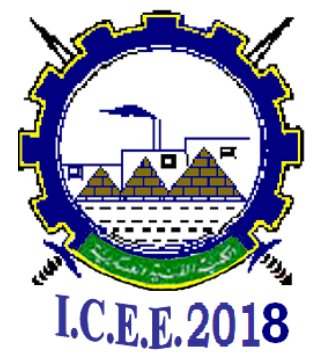

$9^{\text {th }}$ International Conference on

Chemical \& Environmental

Engineering

3-5 April 2018

Effect of the preconcentration time $\left(t_{a c c}\right)$ on SW-AdASV peak current magnitude was then investigated at accumulation potential $0.0 \mathrm{~V}$. It was found that the response for $5.0 \times 10^{-7}$ and $2.0 \times 10^{-7} \mathrm{M} \mathrm{MV} . \mathrm{HCl}$ was linear up to 60 and $100 \mathrm{~s}$ respectively then leveled off (Fig. 7).This indicated that the adsorptive equilibrium onto DA/CPE surface was achieved i.e, full surface coverage was approached. In the present analytical study, $t_{a c c}$ of 90 was applied.

\subsection{Validation of the analytical method}

Voltammograms of various concentrations of $\mathrm{MV} . \mathrm{HCl}$ were recorded under the optimized operational conditions of the developed SW-AdASV method. Linear variation of $i_{p}(\mu \mathrm{A})$ with concentrations $\mathrm{C}(\mathrm{nM})$ of bulk $\mathrm{MV} . \mathrm{HCl}$ was obtained over a wide concentration range (Fig. 8A). Limits of detection (LOD) and quantitation (LOQ) were estimated using the expressions $(2,3)[28]$ :

$$
\begin{aligned}
& \mathrm{LOD}=3 \mathrm{~S} . \mathrm{D} / \mathrm{b} \\
& \mathrm{LOQ}=10 \mathrm{~S} . \mathrm{D} / \mathrm{b},
\end{aligned}
$$

Where, S.D is the standard deviation of the intercept of the calibration curves (or the blank) and $\mathrm{b}$ is the slope of the calibration curve. The obtained results and the corresponding regression equations were listed in (Table 2). These results indicated the extreme sensitivity and reliability of the proposed SW-AdASV method for quantification of bulk MV.HCl.

Repeatability, reproducibility, precision and accuracy[29] of the proposed SW-AdASV methods were evaluated by performing five replicate measurements for various concentrations of MV.HCl, $\left(5 \times 10^{-8} 1 \times 10^{-7} 1.2 \times 10^{-7}\right) \mathrm{M}$ [over 1 day (intra-day assay) and for 3 days (inter-day assay)] using DA/CPE, (Table 3). Satisfactory mean recoveries (\%R $\pm \mathrm{RSD} \%)(98.40 \pm 1.01$ to $101.10 \pm 0.65)$ and bias\% were achieved indicating the repeatability, reproducibility, precision and accuracy of the described method.

The robustness[29] of the proposed method was examined by studying the effect of small variation of some effective operational conditions such as $\mathrm{pH}$ (4.5 to 5.5), accumulation potential (-0.05 to 0.05 ), and accumulation time ( 85 to $95 \mathrm{~s}$ ) on \%R and RSD\% (Table 4). Since, the obtained $\% \mathrm{R}$ and $\% \mathrm{RSD}$ values (103.83 \pm 0.91 to $97.52 \pm 1.13)$ were insignificantly affected within the studied range of variation of the operational conditions, the developed SW-AdASV method could be considered robust. 


\section{Military Technical College \\ Kobry El-Kobbah, Cairo, Egypt}

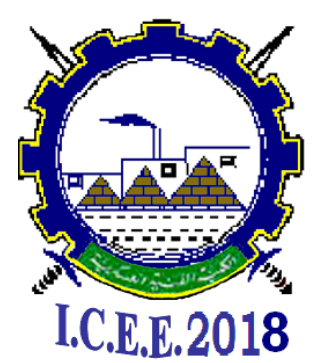

$9^{\text {th }}$ International Conference on

Chemical \& Environmental Engineering

3-5 April 2018

\section{Application}

The developed SW-AdASV was successfully applied in determination of $\mathrm{MV} . \mathrm{HCl}$ in serum by recording voltammograms of various concentrations of $\mathrm{MV} . \mathrm{HCl}$ in serum under the optimized operational conditions of the developed SW-AdASV method. Linear variation of $i_{p}(\mu \mathrm{A})$ with concentrations $\mathrm{C}(\mathrm{nM})$ of bulk $\mathrm{MV} . \mathrm{HCl}$ was obtained over a wide concentration range $5 \times 10^{-9}-1.6 \times 10^{-7}$ (Fig. 8b), the charactaristics of the callipratipn are in (Table 2).

MV.HCl was determined in its different pharmaceutical formulations Colofac ${ }^{\circledR}$ tablets (135 mg mebeverine) also as a binary as binary mixture with Sulpiride (SPR) drug in Colona tablets ${ }^{\circledR}(100 \mathrm{mg}$ mebeverine $+25 \mathrm{mg}$ sulpiride $)$ and with chloridazepoxide (CDP) drug in Coloverin $A \circledR$ tablets (135 mg mebeverine $+5 \mathrm{mg}$ chloridazepoxide). Furthermore, the performance of the DP-AdASV method was also assessed by the calculation of Student $t$-test and $F$-values[30] compared with the SW-AdASV. (Table 5) showed a good agreement with the results of the HPLC and that the calculated $t$ - and $F$ values at $95 \%$ confidence limit for five degrees of freedom did not exceed the theoretical values[30]. This indicated that both the developed SW-AdASV and RP-HPLC methods did not differ significantly with respect to accuracy and precision. Hence, the developed SW-AdASV method was found to be sensitive, accurate, precise, repeatable and reproducible and can be successfully used for the routine analysis of $\mathrm{MV} . \mathrm{HCl}$ in its formulations.

\section{Conclusion}

Mebeverine hydrochloride was easily determined in its pharmaceutical formulation and biological fluid utilizing $5 \%(\mathrm{w} / \mathrm{w}) \mathrm{DA} / \mathrm{CPE}$, the modifier used is green as $\mathrm{t}$ needs no chemical modification and has no hazard. The utilized method is fast, reliable, precise, and robust in addition to the validity of the method that were investigated using $F$-test and $t$-test for determination of $\mathrm{MV}$. $\mathrm{HCl}$ in different pharmaceutical formulations with different conc and different additives reflecting selectivity too.

\section{Refrances}

[1] Zayed, S.I.M., Simultaneous determination of mebeverine hydrochloride and sulpiride using the first derivatives of ratio spectra and chemometric methods. Analytical sciences, 2005. 21(8): p. 985-989.

[2] Reme, S.E., et al., Mediators of change in cognitive behaviour therapy and mebeverine for irritable bowel syndrome. Psychological medicine, 2011. 41(12): p. 2669-2679. 
Military Technical College

Kobry El-Kobbah, Cairo, Egypt

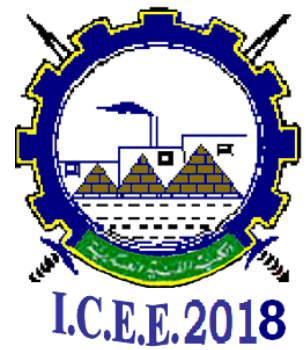

$9^{\text {th }}$ International Conference on

Chemical \& Environmental Engineering

3-5 April 2018

[3] Haggag, R.S., R.A. Shaalan, and T.S. Belal, Validated HPLC determination of the two fixed dose combinations (chlordiazepoxide hydrochloride and mebeverine hydrochloride; carvedilol and hydrochlorothiazide) in their tablets. Journal of AOAC International, 2010. 93(4): p. 1192-1200.

[4] Swetha, A.V., et al., Development and validation of new analytical methods for the assay of Mebeverine hydrochloride in tablet dosage form. International Journal of Advances in Pharmaceutical Research Oct, 2015. 6(10): p. 320-331.

[5] Arayne, M.S., N. Sultana, and F.A. Siddiqui, A new RP-HPLC method for analysis of mebeverine hydrochloride in raw materials and tablets. Pakistan journal of pharmaceutical sciences, 2005. 18(2): p. 11-14.

[6] Stockis, A., P.J.M. Guelen, and D. De Vos, Identification of mebeverine acid as the main circulating metabolite of mebeverine in man. Journal of pharmaceutical and Biomedical Analysis, 2002. 29(1): p. 335-340.

[7] Walash, M.I., et al., Simultaneous determination of sulpiride and mebeverine by HPLC method using fluorescence detection: application to real human plasma. Chemistry Central Journal, 2012. 6(1): p. 1-12.

[8] Siddiqui, F.A., et al., Spectrophotometric Multivariate Calibration Approach: Application in Quantitative Determination of Mebeverine in Bulk Drug and Pharmaceutical Formulations. World Applied Sciences Journal, 2014. 32(7): p. 1418-1422.

[9] Naveed, S., et al., Method Development of Mebeverine Hydrochloride by Using UV Spectrophotometric Method. International Journal of Applied ScienceResearch and Review, 2015. 2(1): p. 001-005.

[10] El-Didamony, A.M., Spectrophotometric determination of benzydamine $\mathrm{HCl}$, levamisole $\mathrm{HCl}$ and mebeverine $\mathrm{HCl}$ through ion-pair complex formation with methyl orange. Spectrochimica Acta Part A: Molecular and Biomolecular Spectroscopy, 2008. 69(3): p. 770-775.

[11] Lotfy, H.M., et al., Simultaneous determination of mebeverine hydrochloride and chlordiazepoxide in their binary mixture using novel univariate spectrophotometric methods via different manipulation pathways. Spectrochimica Acta Part A: Molecular and Biomolecular Spectroscopy, 2016. 155: p. 11-20.

[12] Tulich, L.J., et al., Determination of two mebeverine metabolites, mebeverine alcohol and desmethylmebeverine alcohol, in human plasma by a dual stable isotope-based gas chromatographic-mass spectrometric method. Journal of Chromatography B: Biomedical Sciences and Applications, 1996. 682(2): p. 273281. 
Military Technical College

Kobry El-Kobbah, Cairo, Egypt

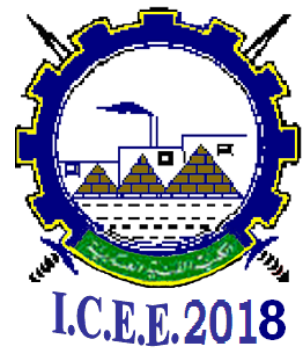

$9^{\text {th }}$ International Conference on

Chemical \& Environmental Engineering

3-5 April 2018

[13] Ali, T.A., et al., Improved Determination of Mebeverine Hydrochloride in Urine, Serum and Pharmaceutical Preparations Utilizing a Modified Carbon Paste Electrode. Int. J. Electrochem. Sci, 2015. 10: p. 2439-2454.

[14] Naggar A. H., Kotb A., Gahlan A. A. and El-Sayed A. Y., Square wave anodic stripping voltammetric determination of Mebeverin hydrochloride in tablet and urine at carbon paste electrode. Applied Chemistry, 2014. 77: p. 29391-29394.

[15] Salama, N.N., et al., Utility of gold nanoparticles/silica modified electrode for rapid selective determination of mebeverine in micellar medium: comparative discussion and application in human serum. Ionics, 2016. 22(6): p. 957-966.

[16] Ghoneim, M.M., H.S. El-Desoky, and F.M. El-badawy, Carbon Nanotubes Modified Electrode for Enhanced Voltammetric Sensing of Mebeverine Hydrochloride in Formulations and Human Serum Samples Journal of The Electrochemical Society, 2017. 164(6): p. B212-B222.

[17] Caliskan, N., et al., The natural diatomite from caldiran-van (Turkey): electroanalytical application to antimigraine compound naratriptan at modified carbon paste electrode. Combinatorial Chemistry \& High Throughput Screening, 2010. 13(8): p. 703-711.

[18] Zhuravlev, L.T., The surface chemistry of amorphous silica. Zhuravlev model. Colloids and Surfaces A: Physicochemical and Engineering Aspects, 2000. 173(1): p. 1-38.

[19] Al-Ghouti, M.A., et al., The removal of dyes from textile wastewater: a study of the physical characteristics and adsorption mechanisms of diatomaceous earth. Journal of Environmental Management, 2003. 69(3): p. 229-238.

[20] Farmer, V.C., Infrared spectra of minerals Mineralogical society. 1974.

[21] Yitagesu, F.A., et al., Spectral characteristics of clay minerals in the $2.5-14 \mu \mathrm{m}$ wavelength region. Applied clay science, 2011. 53(4): p. 581-591.

[22] Rajan, A.S., S. Sampath, and A.K. Shukla, An in situ carbon-grafted alkaline iron electrode for iron-based accumulators. Energy \& Environmental Science, 2014. 7(3): p. 1110-1116.

[23] Siddiqui, I., M.T. Shah, and I. Ahmed, X-RAY Diffraction (XRD) Analyses OF Thar, Sonda And Meting-Jhimpir Coalfields, SINDH. Sindh University Research Journal-SURJ (Science Series), 2009. 41(1).

[24] Allen, et al., Electrochemical methods: fundamentals and applications. University of Texas at Austin, John Wiley \& Sons, Inc, 2001: p. 156-176.

[25] McCreery, R.L., Carbon electrodes: structural effects on electron transfer kinetics. Electroanalytical chemistry, 1991. 17: p. 221-374. 
Military Technical College Kobry El-Kobbah, Cairo, Egypt

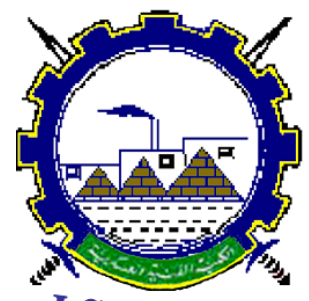

I.C.E.E.2018 $9^{\text {th }}$ International Conference on

Chemical \& Environmental Engineering

3-5 April 2018

[26] Ghoneim, M.M., et al., Nano Determination of Kinase Inhibitor Sorafenib Drug in Pharmaceutical Formulation and Human Blood at a Modified Carbon Paste Electrode. Journal of The Electrochemical Society, 2016. 163(6): p. B215-B226.

[27] Manisankar, P., G. Selvanathan, and C. Vedhi, Utilization of sodium montmorillonite clay-modified electrode for the determination of isoproturon and carbendazim in soil and water samples. Applied clay science, 2005. 29(3): p. 249257.

[28] Miller, J.N., Basic statistical methods for analytical chemistry. Part 2. Calibration and regression methods. A review. Analyst, 1991. 116(1): p. 3-14.

[29] Validation of analytical procedures: text and methodology Q2(R1), International Conference On Harmonization Of Technical Requirements For Registration Of Pharmaceuticals For Human Use Guideline, Geneva, Switzerland, 2005, 1-13.

[30] Harvey, D., Modern analytical chemistry McGraw-Hill New York, 2000: p. 727728. 
Military Technical College Kobry El-Kobbah, Cairo, Egypt

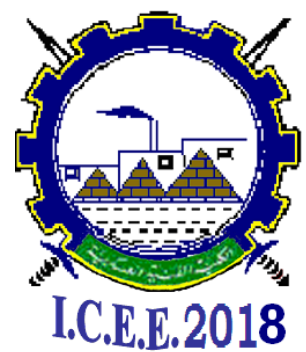

$9^{\text {th }}$ International Conference on

Chemical \& Environmental Engineering 3-5 April 2018

Table 1 Comparison of the quantitation limits of the reported electrochemical methods to that of the described SW-AdASV method for Mebeverin hydrochloride determination at carbon past electrode (CPE) or the modified ones.

\begin{tabular}{|c|c|c|c|c|}
\hline Method & Electrode & Linear range $\backslash \mathrm{M}$ & LOQ $\backslash \mathrm{M}$ & Ref. \\
\hline $\begin{array}{c}\frac{\text { Potentiometr }}{\mathbf{y}} \\
\text { Bulk form }\end{array}$ & $\begin{array}{c}\text { Tricresylphosphate/CPE } \\
o \text {-nitrophenyloctylether/CPE }\end{array}$ & $\begin{array}{l}3.0 \times 10^{-7}-1.0 \times 10^{-2} \\
1.0 \times 10^{-7}-1.0 \times 10^{-2}\end{array}$ & $\begin{array}{l}1.00 \times 10^{-6} \\
3.33 \times 10^{-7}\end{array}$ & [13] \\
\hline $\begin{array}{l}\text { SW-AdASV } \\
\text { Bulk form } \\
\text { Human urine }\end{array}$ & $\mathrm{CPE}$ & $\begin{array}{l}4.9 \times 10^{-7}-9.0 \times 10^{-6} \\
7.5 \times 10^{-7}-9.0 \times 10^{-6}\end{array}$ & $\begin{array}{l}2.72 \times 10^{-6} \\
7.87 \times 10^{-7}\end{array}$ & [14] \\
\hline $\begin{array}{c}\text { DPV } \\
\text { Bulk form } \\
\text { Human serum }\end{array}$ & $\begin{array}{l}\text { Gold nanoparticles / silica } \\
\text { gel / CPE }\end{array}$ & $\begin{array}{l}4.0 \times 10^{-8}-1.0 \times 10^{-5} \\
2.0 \times 10^{-7}-9.0 \times 10^{-6}\end{array}$ & $\begin{array}{l}5.0 \times 10^{-9} \\
6.7 \times 10^{-8}\end{array}$ & [15] \\
\hline $\begin{array}{l}\text { SW-AdASV } \\
\text { Bulk form } \\
\text { Human serum }\end{array}$ & $\begin{array}{l}\text { functionalized multiwall } \\
\text { carbon nanotube /CPE }\end{array}$ & $\begin{array}{l}5.0 \times 10^{-10}-3.5 \times 10^{-8} \\
8.0 \times 10^{-10}-2.0 \times 10^{-8}\end{array}$ & $\begin{array}{l}4.4 \times 10^{-10} \\
6.7 \times 10^{-10}\end{array}$ & [16] \\
\hline $\begin{array}{l}\text { SW-AdASV } \\
\text { Bulk form } \\
\text { Human serum }\end{array}$ & diatom /CPE & $\begin{array}{c}5.0 \times 10^{-9}-2.0 \times 10^{-7} \\
8.0 \times 10^{-10}-2.0 \times 10^{-8}\end{array}$ & $6.00 \times 10^{-9}$ & $\underline{\text { This }}$ \\
\hline
\end{tabular}

Table 2: Characteristics of the calibration curves of SW-AdASV determination of bulk (MV.HCL) in a B-R universal buffer of $\mathrm{pH} 5$; under the optimal operational conditions.

\begin{tabular}{ccc}
\hline & Bulk & Serum \\
\hline Linearity range/ $(\mathrm{M})$ & $5.0 \times 10^{-9}-2 \times 10^{-7}$ & $5 \times 10^{-9}-1.6 \times 10^{-7}$ \\
\hline Slope / $\mu \mathrm{AA} / \mathrm{nM})$ & 0.035 & 0.107 \\
S.D & 0.011 & $2.16 \times 10^{-2}$ \\
S.E & 0.0055 & $8.82 \times 10^{-2}$ \\
Intercept / $(\mu \mathrm{A})$ & 0.64 & 0.113 \\
S.D & 0.021 & $8.91 \times 10^{-2}$ \\
SE & 0.0105 & $3.64 \times 10^{-2}$ \\
Correlation coefficient $(r)$ & $0.996 \pm 0.002$ & $0.997 \pm 0.002$ \\
Number of points $(N)$ & 11 & 13 \\
Mean $L O Q /(\mathrm{M})$ & $6.00 \times 10^{-9}$ & $2.50 \times 10^{-9}$ \\
Mean $L O D /(\mathrm{M})$ & $1.80 \times 10^{-9}$ & $8.33 \times 10^{-9}$ \\
\hline
\end{tabular}

\section{$\mathrm{N}=4$}


Military Technical College Kobry El-Kobbah, Cairo, Egypt

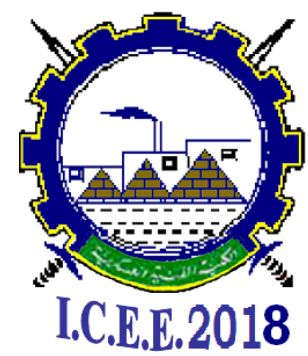

$9^{\text {th }}$ International Conference on

Chemical \& Environmental Engineering 3-5 April 2018

Table3. Results of intra-day and inter-day assays of various concentrations of bulk (MV.HCL) by the optimized SW-AdASV method utilizing using DA/CPE

\begin{tabular}{|c|c|c|c|c|c|}
\hline Day & $\begin{array}{c}\text { [Taken] / } \\
\text { M }\end{array}$ & $\begin{array}{c}\text { Mean[Found] } \\
\text { M }\end{array}$ & $\% \mathrm{R}$ & $\%$ Bias & $\begin{array}{c}\text { Precision } \\
\text { RSD \% }\end{array}$ \\
\hline \multicolumn{6}{|c|}{ Intra-day } \\
\hline & $1 \times 10^{-8}$ & $0.994 \times 10^{-8}$ & 99.36 & -0.64 & 0.73 \\
\hline & $1 \times 10^{-7}$ & $1.004 \times 10^{-7}$ & 100.4 & -0.4 & 0.62 \\
\hline & $1.2 \times 10^{-7}$ & $1.199 \times 10^{-7}$ & 99.94 & 0.12 & 0.49 \\
\hline \multicolumn{6}{|c|}{ Inter-day } \\
\hline \multirow{3}{*}{1} & $5 \times 10^{-8}$ & $4.921 \times 10^{-8}$ & 98.40 & -1.58 & 1.01 \\
\hline & $1 \times 10^{-7}$ & $0.998 \times 10^{-7}$ & 99.81 & -0.19 & 0.81 \\
\hline & $1.2 \times 10^{-7}$ & $1.195 \times 10^{-7}$ & 99.58 & -0.42 & 0.73 \\
\hline \multirow{3}{*}{2} & $5 \times 10^{-8}$ & $5.001 \times 10^{-8}$ & 100.02 & 0.02 & 0.32 \\
\hline & $1 \times 10^{-7}$ & $1.002 \times 10^{-7}$ & 100.22 & 0.22 & 0.17 \\
\hline & $1.2 \times 10^{-7}$ & $1.202 \times 10^{-7}$ & 100.17 & 0.17 & 0.25 \\
\hline \multirow{3}{*}{3} & $5 \times 10^{-8}$ & $4.982 \times 10^{-8}$ & 99.64 & -0.36 & 0.92 \\
\hline & $1 \times 10^{-7}$ & $1.011 \times 10^{-7}$ & 101.10 & 1.10 & 0.65 \\
\hline & $1.2 \times 10^{-7}$ & $1.201 \times 10^{-7}$ & 100.08 & 0.08 & 0.51 \\
\hline
\end{tabular}

Table4: Validation studies for determination of $2 \times 10^{-8} \mathrm{M}$ bulk (MV.HCL) by means of the described SW-AdASV method onto DA/CPE.

\begin{tabular}{ccc}
\hline Variables & $\begin{array}{c}\text { Operational } \\
\text { Conditions }\end{array}$ & $\begin{array}{c}\mathbf{R} \pm \mathbf{R S D} \% \\
(\mathbf{n}=\mathbf{3})\end{array}$ \\
\hline $\mathrm{pH}$ & $\mathrm{E}_{\mathrm{acc}}=0.0 \mathrm{~V}$ & $98.87 \pm 0.92$ \\
4.5 & & $99.55 \pm 0.98$ \\
5.0 & & $99.21 \pm 0.52$ \\
5.5 & & \\
\hline Preconcentration potential & & \\
$\left(E_{a c c}\right)$ & $\mathrm{pH}=5$ & $99.39 \pm 0.77$ \\
-0.05 & & $99.55 \pm 0.98$ \\
0.0 & & $99.99 \pm 0.63$ \\
0.05 & & \\
85 & $\mathrm{pH}=5$, & $97.52 \pm 1.13$ \\
90 & $\mathrm{E}_{\mathrm{acc}}=-0.20 \mathrm{~V}$ & $99.55 \pm 0.98$ \\
95 & & $103.83 \pm 0.91$ \\
\hline
\end{tabular}


Military Technical College Kobry El-Kobbah, Cairo, Egypt

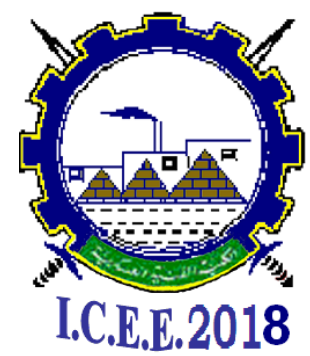

$9^{\text {th }}$ International Conference on

Chemical \& Environmental Engineering

3-5 April 2018

Table 5: Assay of (MV.HCl) in its pharmaceutical formulations by means of the described stripping voltammetric method in comparison with f-MWCNT/CPE method

\begin{tabular}{|c|c|c|c|c|c|}
\hline Method & $\begin{array}{c}\text { TTaken }] \\
\text { (mg/tablet) }\end{array}$ & $\begin{array}{l}\text { Mean [Found] } \\
/ \text { (mg/tablet) }\end{array}$ & $\% \mathrm{R}$ & $\%$ Bias & $\begin{array}{l}\text { Precision } \\
\text { RSD \% }\end{array}$ \\
\hline \multicolumn{6}{|c|}{ Colofac $\AA$} \\
\hline DA/CPE & 135 & 134.45 & 99.59 & 0.41 & 0.55 \\
\hline 7\%f-MWCNT/CPE & 135 & 133.64 & 98.99 & 1.01 & 0.45 \\
\hline F-value & 1.49 & & & & \\
\hline t-test & 1.89 & & & & \\
\hline \multicolumn{6}{|c|}{$\overline{\text { Colona }{ }^{\circledR}}$} \\
\hline DA/CPE & 100 & 99.21 & 99.21 & 0.79 & 0.63 \\
\hline 7\%f-MWCNT/CPE & 100 & 99.85 & 99.85 & 0.15 & 0.66 \\
\hline F-value & 1.10 & & & & \\
\hline t-test & 1.57 & & & & \\
\hline \multicolumn{6}{|c|}{ 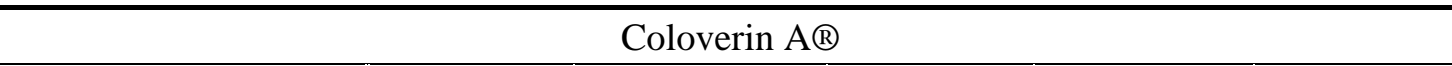 } \\
\hline DA/CPE & 135 & 134.77 & 99.83 & 0.17 & 0.67 \\
\hline f-MWCNT/CPE & 135 & 134.01 & 99.27 & 0.73 & 0.58 \\
\hline F-value & 1.33 & & & & \\
\hline t-test & 1.41 & & & & \\
\hline
\end{tabular}

Theoretical $F$-value ,, $\mathrm{F}(0.05,4,4)=6.388$ and $t$-test, $\mathrm{t}(0.05,7)=2.36$ at $95 \%$ confidence limit for $\mathrm{n}_{1}=5$ and $\mathrm{n}_{2}=5$. 
Military Technical College

Kobry El-Kobbah,

Cairo, Egypt

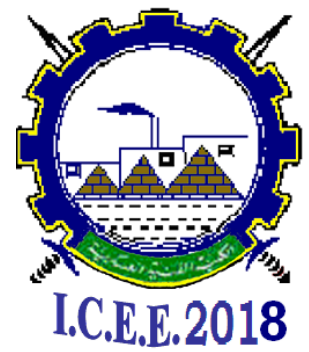

$\mathrm{HCl}$<smiles>CCN(CCCCOC(=O)c1ccc(OC)c(OC)c1)C(C)Cc1ccc(OC)cc1</smiles>

$9^{\text {th }}$ International Conference on

Chemical \& Environmental

Engineering

3-5 April 2018

Fig.1. Chemical structure of Mebeverine hydrochloride (MV.HCl)
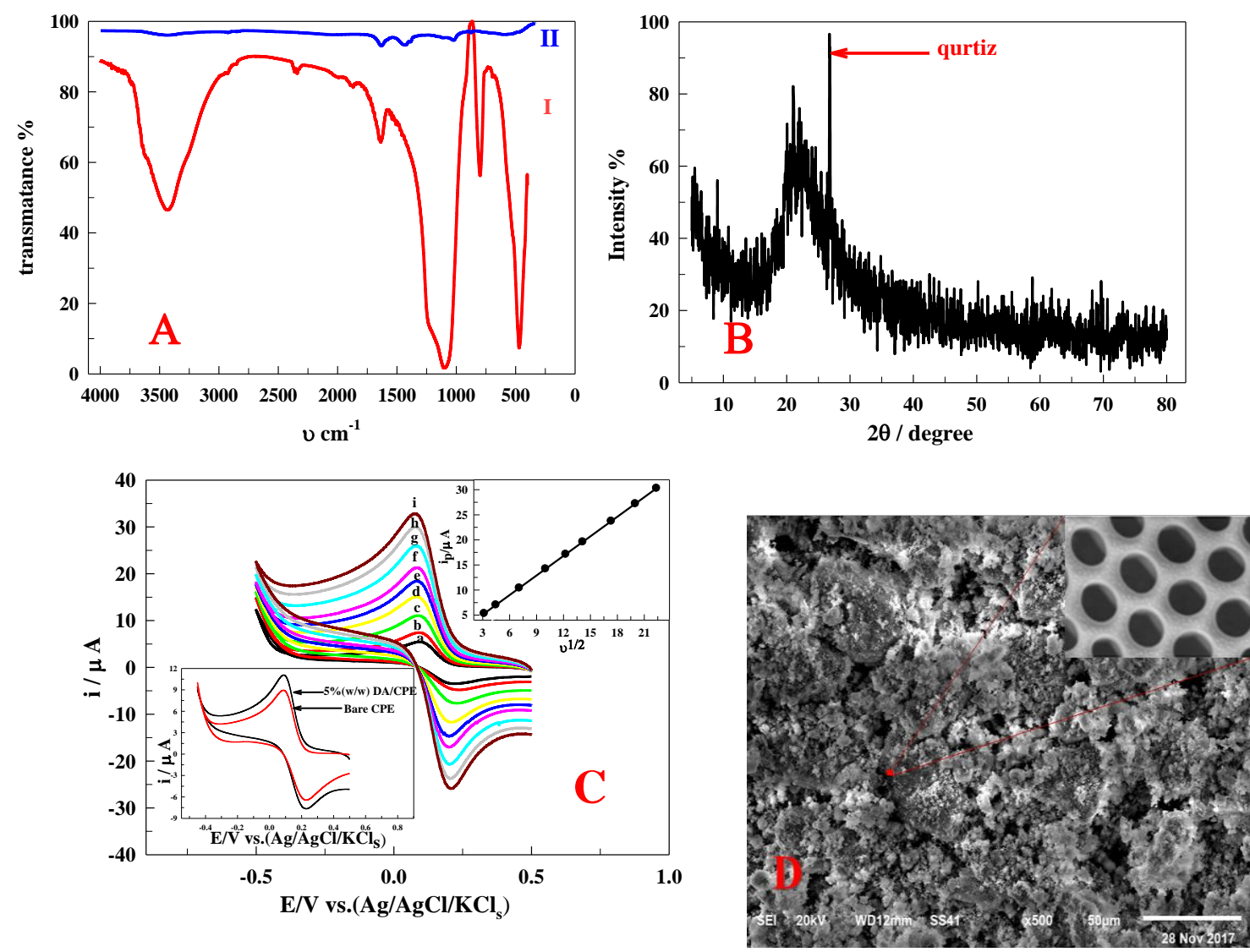

Fig. 2: A) FTIR of (I) for diatom (II) graphite and, B) XRD for diatom, C) cyclic voltammetry for $1.0 \times 10^{-3} \mathrm{M} \mathrm{K} \mathrm{K}_{4} \mathrm{Fe}(\mathrm{CN})_{6}$ onto $5 \%$ (w/w)DA/CPE and D) SEM of diatom. 
Military Technical College

Kobry El-Kobbah,

Cairo, Egypt
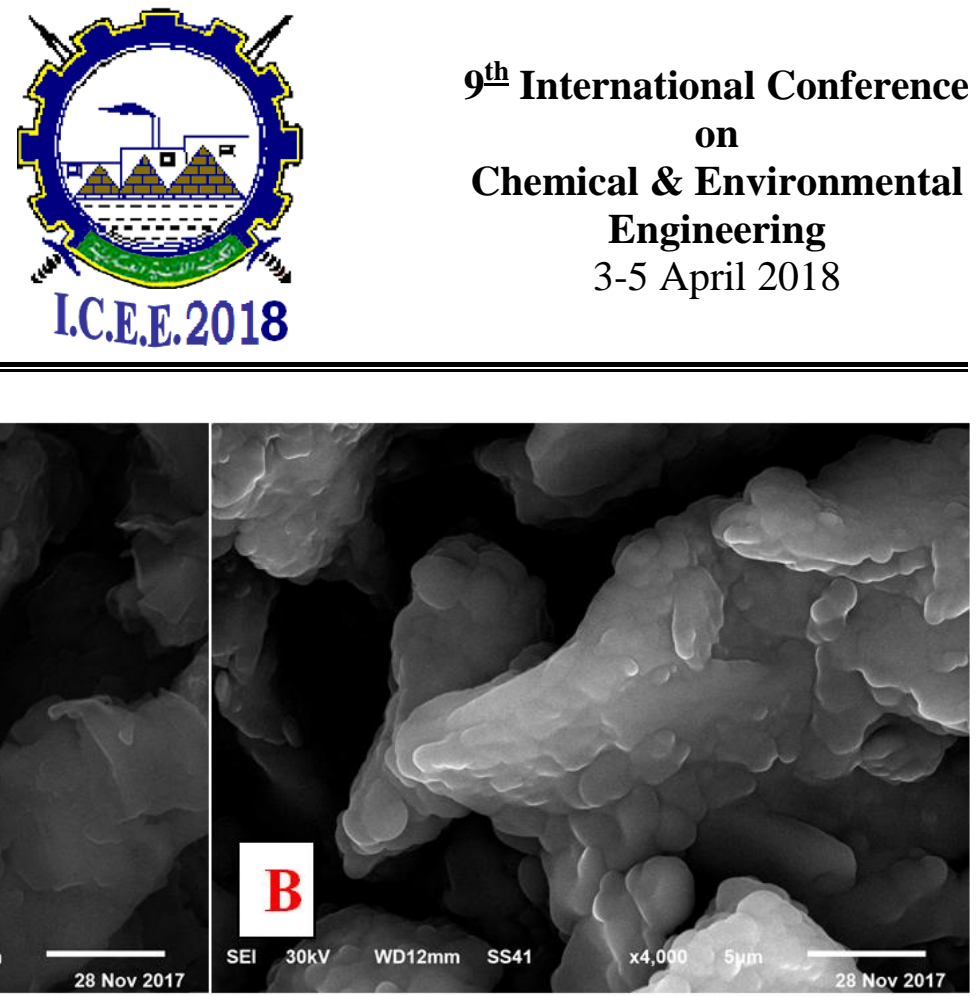

Fig. 3: SEM image for A) CPE and B) 5\% (w/w)DA/CPE
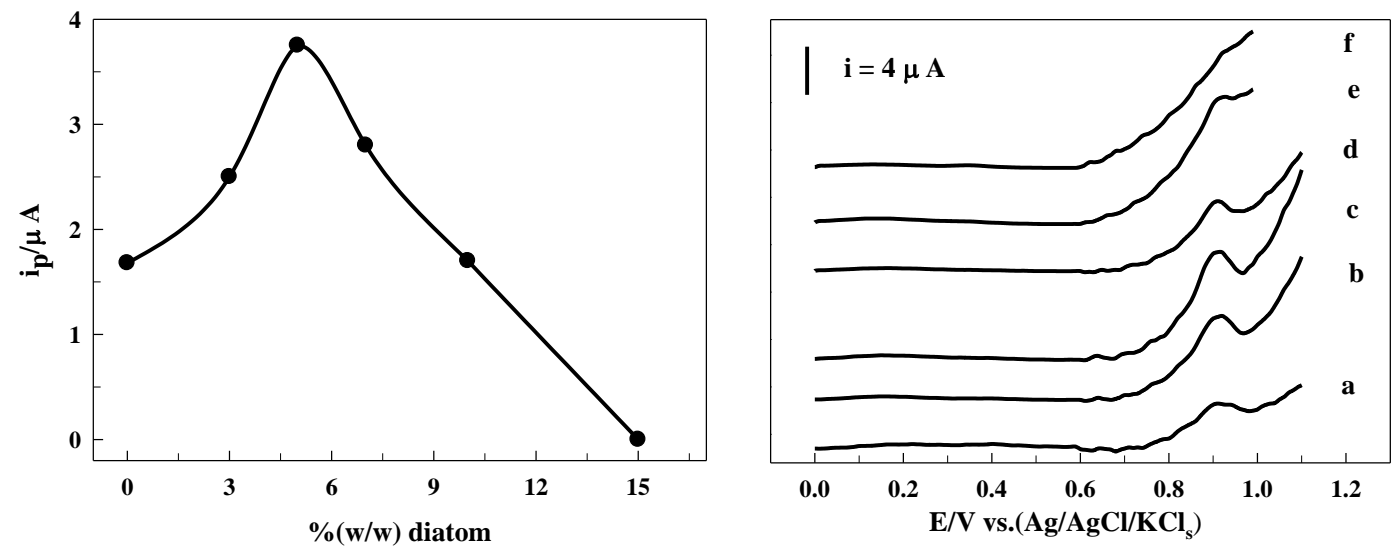

Fig. 4: SW-AdASV chromatogram of $5 \times 10^{-7} \mathrm{M}$ MV.HCl in B-R universal buffer of pH 5 onto CPE modified by different ratios of diatoms. 


\begin{tabular}{|l|l|}
\hline Proceeding of the $9^{\text {th }}$ ICEE Conference 3-5 April 2018 & CEA
\end{tabular}

Military Technical College

Kobry El-Kobbah,

Cairo, Egypt

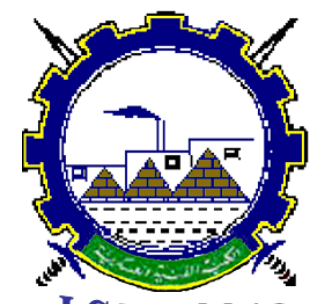

I.C.E.E.2018 $9^{\text {th }}$ International Conference on

Chemical \& Environmental

Engineering

3-5 April 2018
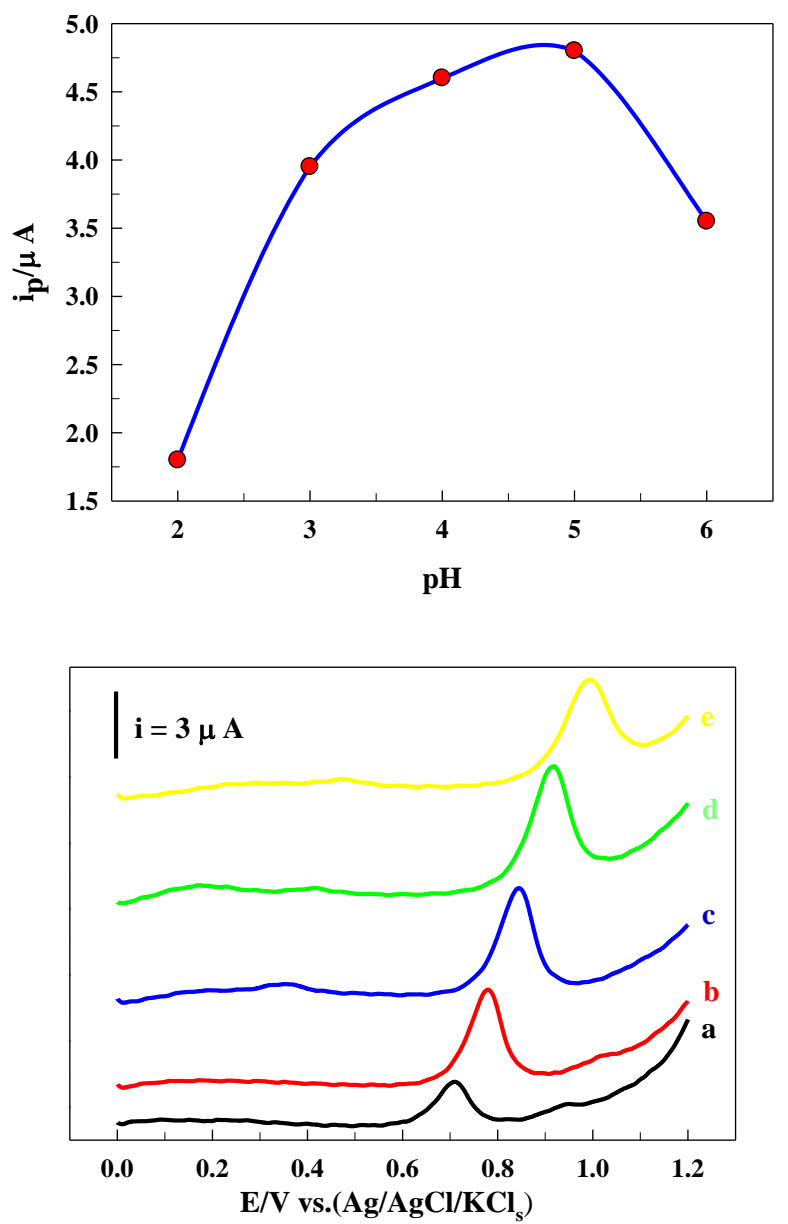

Fig. 5: Voltammograms and its corresponding plot for the effect of $\mathrm{pH}$ on the $\mathrm{SW}$ AdASV peak current intensity for $5 \times 10^{-7} \mathrm{M}$ of (MV.HCl) 
Military Technical College

Kobry El-Kobbah,

Cairo, Egypt

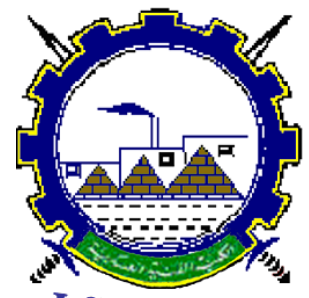

I.C.E.E.2018 $9^{\text {th }}$ International Conference on

Chemical \& Environmental

Engineering

3-5 April 2018

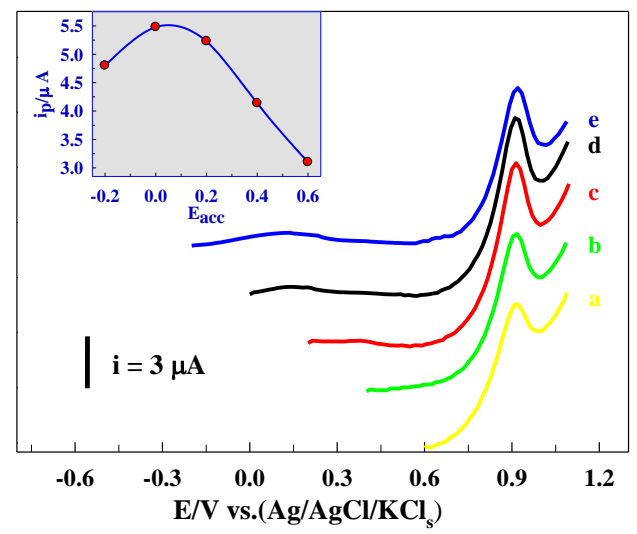

Fig. 6: Voltammograms and its corresponding plots for the effect of accumulation potential on the SW-AdASV peak current intensity for $5 \times 10^{-7} \mathrm{M}$ of $(\mathrm{MV} . \mathrm{HCl})$ in the B-R universal buffer solution of $\mathrm{pH} 5$

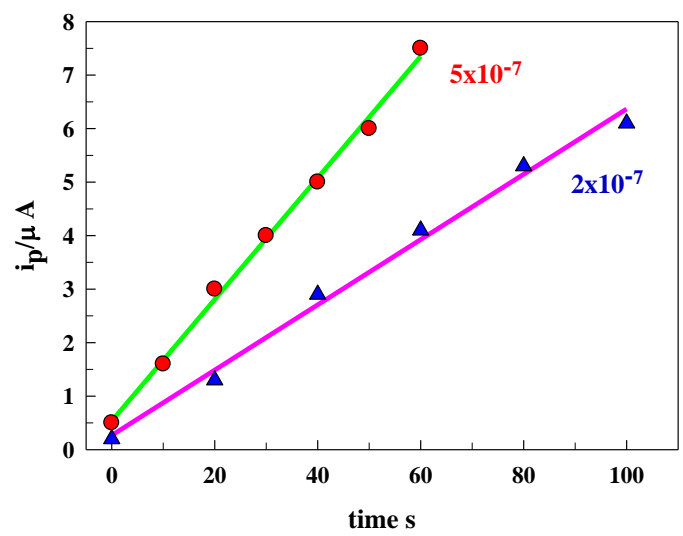

Fig. 7: Voltammograms and its corresponding plots for the effect of accumulation time on the SW-AdASV peak current intensity for $5 \times 10^{-7}$ and $2 \times 10^{-7} \mathrm{M}$ of (MV.HCl) in the B-R universal buffer solution of $\mathrm{pH} 5$ 
Military Technical College

Kobry El-Kobbah,

Cairo, Egypt
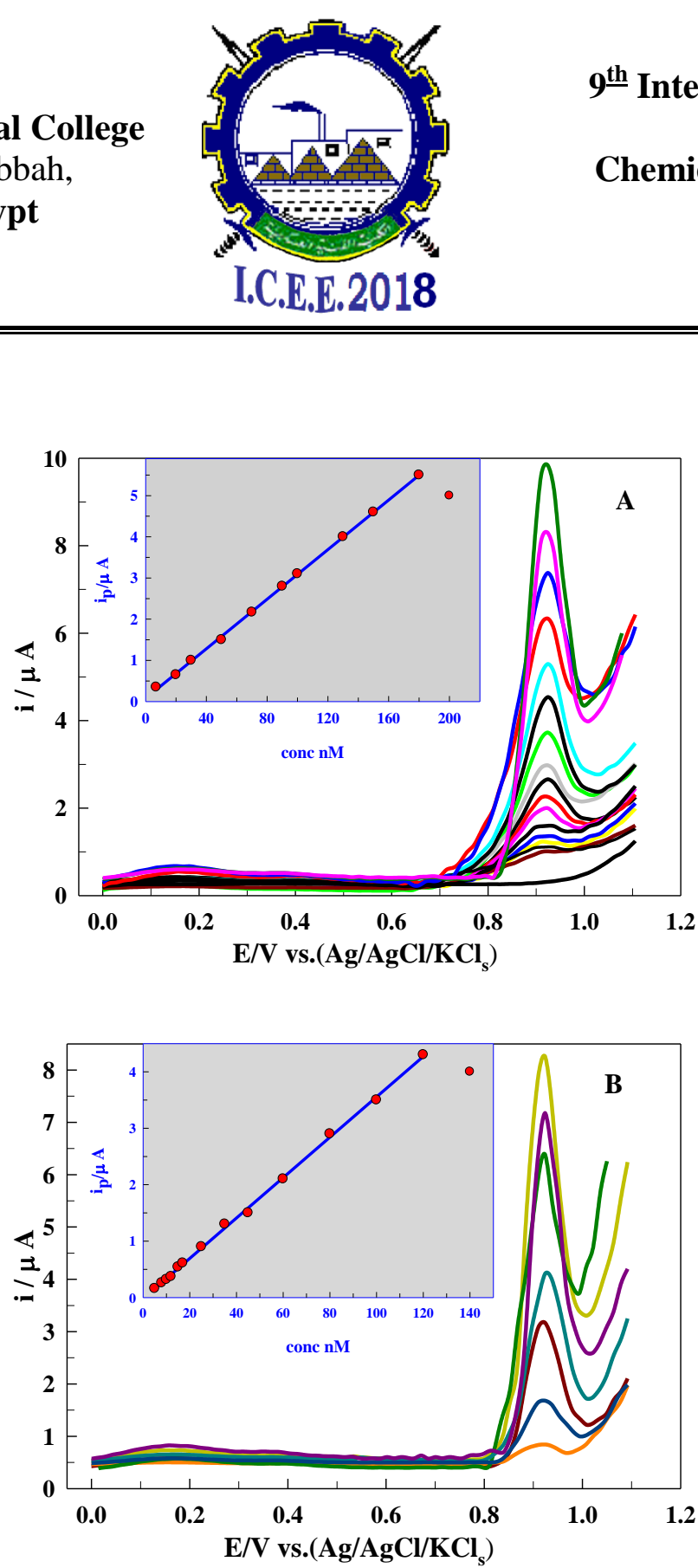

Fig. 8: SW-AdAS voltammograms recorded in the B-R buffer of pH 5 for various concentrations of (MV.HCl) A) in bulk and B) in serum at DA/CPE after preconcentration for 100 . 